OECD Health Working Papers No. 51

Effective Ways to Realise Policy Reforms in Health

\title{
Jeremy Hurst
}

Systems

https://dx.doi.org/10.1787/5kmh377/4n9x-en 
Organisation de Coopération et de Développement Économiques

Organisation for Economic Co-operation and Development

29-Mar-2010

DIRECTORATE FOR EMPLOYMENT, LABOUR AND SOCIAL AFFAIRS

English text only HEALTH COMMITTEE

\section{Health Working Papers}

OECD Health Working papers No. 51

EFFECTIVE WAYS TO REALISE POLICY REFORMS IN HEALTH SYSTEMS

Jeremy Hurst

JEL Classification: I18; D72; D78

All Health Working Papers are now available through OECD's Internet website at http://www.oecd.org/els 


\title{
DIRECTORATE FOR EMPLOYMENT, LABOUR AND SOCIAL AFFAIRS
}

\author{
www.oecd.org/els
}

\section{OECD HEALTH WORKING PAPERS}

\author{
http://www.oecd.org/els/health/workingpapers
}

This series is designed to make available to a wider readership health studies prepared for use within the OECD. Authorship is usually collective, but principal writers are named. The papers are generally available only in their original language - English or French - with a summary in the other.

Comment on the series is welcome, and should be sent to the Directorate for Employment, Labour and Social Affairs, 2, rue André-Pascal, 75775 PARIS CEDEX 16, France.

The opinions expressed and arguments employed here are the responsibility of the author(s) and do not necessarily reflect those of the OECD.

\section{Applications for permission to reproduce or translate all or part of this material should be made to:}

\author{
Head of Publications Service \\ OECD \\ 2, rue André-Pascal \\ 75775 Paris, CEDEX 16 \\ France
}

Copyright OECD 2010 


\section{SUMMARY}

1. Sometimes it is argued that the content of a reform is less important in determining whether or not it receives public and legislative approval than the timing of the proposal; the way in which the reform is presented; the discussions with stakeholders; and a multitude of other factors. The OECD has a crosscutting project on these issues, entitled Making Reform Happen. A number of OECD directorates are considering the factors lying behind successful implementation of reforms in their different policy areas, including tax, environment, agriculture, trade, competition, education, health, pensions, product markets and labour markets.

2. This paper is a contribution to the wider OECD project. It is based on evidence from the countries which have seen their health systems reviewed by the OECD in recent years, and on a selected review of the literature. It considers four issues in particular, these being the ones used across all the different reform areas covered by the Making Reform Happen project:

- The existence of appropriate institutions to support reforms from decision to implementation.

- The impact on, and reactions of, those affected by the reforms.

- Reform agendas, timing and interactions across different policy areas.

- The role of evidence and international organisations to sustain reforms.

3. It concludes that a number of stages of reform need to be implemented before a reform can be said to be successful; failure in one of them will generally lead to failure of the reform. Issues particular to the health sector include:

- The role of the professional monopolists who provide health services.

- The role of information and evidence.

- The role of international comparisons of health system performance.

- A clear diagnosis and a compelling design for a reform.

- Taking advantage of political 'windows of opportunity'.

- Communication and engagement between the proponents of reforms and other key stakeholders especially those holding veto powers.

- Use of incentives, to align the interests of stakeholders with the intentions of the reform.

- Securing sufficient resources to 'oil the wheels of change'.

4. However, in some cases there may be tradeoffs between: maximising the success and sustainability of health system reforms; maximising the speed at which they are carried out; and minimising the resources that have to be invested in their implementation.

5. There may be a role for the OECD in continuing to look at what works and what does not work in health policy - and what are the determinants of success in health system reforms. 


\section{RÉSUMÉ}

6. D'aucuns arguent parfois que le contenu d'une réforme est moins important pour déterminer son acceptation par le public et par le législateur que le timing de la proposition, la manière dont la réforme est présentée, les discussions avec les parties prenantes et une multitude d'autres facteurs. L'OCDE a lancé un projet transversal sur ces questions sous le titre Making Reform Happen. Un certain nombre de Directions à l'OCDE étudient les facteurs qui sous-tendent le succès des réformes dans leurs différents domaines, notamment la fiscalité, l'environnement, l'agriculture, le commerce, la concurrence et l'éducation, la santé, les réformes des retraites, des marchés de produits et des marchés du travail.

7. Ce rapport est une contribution au projet plus large de l'OCDE. Il se fonde sur des éléments probants émanant de pays dont les systèmes de santé ont fait l'objet d'examens de l'OCDE ces dernières années, et sur un examen choisi de la littérature. Il étudie en particulier les quatre thèmes utilisés dans les différents domaines de réformes s'inscrivant dans le projet Making Reform Happen:

- l'existence d'institutions appropriées pour soutenir les réformes, de la prise de décision à la mise en œuvre ;

- l'impact des réformes sur les personnes qu'elles affectent et les réactions de celles-ci ;

- l'agenda et le calendrier des réformes ainsi que les interactions entre les différents domaines ;

- le rôle des éléments probants et des organisations internationales dans le soutien des réformes.

8. Il conclut à la nécessité de mettre en œuvre un certain nombre de phases de la réforme avant de pouvoir dire qu'une réforme a réussi ; l'échec de l'une de ces phases conduira généralement à l'échec de l'ensemble de la réforme. Certains thèmes sont spécifiques au secteur de la santé, notamment:

- le rôle des professionnels en situation de monopole qui fournissent des services de santé ;

- le rôle des informations et des éléments probants ;

- le rôle des comparaisons internationales des performances des systèmes de santé ;

- un diagnostic clair et une conception contraignante pour une réforme ;

- le fait de profiter des « fenêtres d'opportunité » politiques ;

- la communication et l'engagement entre ceux qui proposent les réformes et les autres parties prenantes, en particulier celles qui détiennent un droit de veto ;

- l'utilisation d'incitatifs pour aligner les intérêts des parties prenantes sur les intentions de la réforme ; 
- le fait de s'assurer de ressources suffisantes pour « mettre de l'huile dans les rouages du changement».

9. Dans certains cas, toutefois, il peut falloir arbitrer entre la maximisation du succès et la viabilité des réformes des systèmes de santé, la maximisation de la vitesse de leur réalisation et la minimisation des ressources à investir dans leur mise en œuvre.

10. L'OCDE peut avoir un rôle à jouer dans la poursuite de l'examen de ce qui marche ou qui ne marche pas dans les politiques de santé, et des éléments qui déterminent le succès des réformes des systèmes de santé. 


\section{TABLE OF CONTENTS}

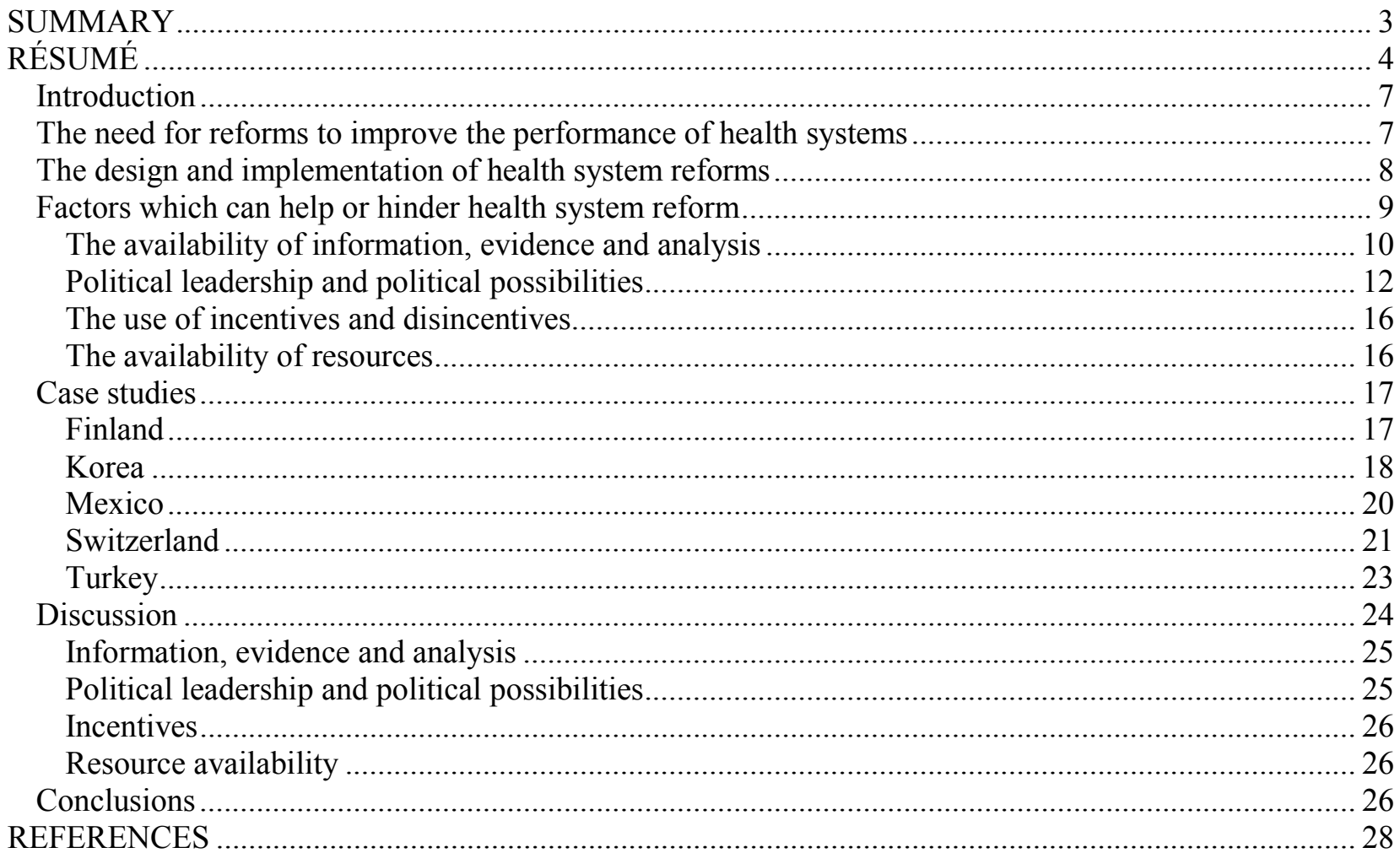




\section{Introduction}

11. This paper contains an investigation of the factors that can help or hinder the reform of health systems in OECD countries. By 'reform' is meant changes to health systems which aim to improve their performance in one or more dimensions. Reforms may or may not be successful. The paper is written mainly from a prescriptive point of view - what should governments do to increase the prospects for successful reforms? It is also written mainly from the perspective of economics, although a few, selected references are made to the political science literature.

12. The first part of the paper considers the need for reform in health systems. It goes on to set out a general framework for examining the determinants of success and failure in health reforms and to focus on the governance of reforming health systems - by identifying some enabling and disabling factors that are likely to be partly under the control of governments. The second part of the paper presents five case studies of the factors associated with successful and unsuccessful reforms, based on five, recent OECD Reviews of Health Systems - in Finland, Korea, Mexico, Switzerland and Turkey, respectively. Two final sections discuss the findings from the case studies and draw some conclusions, respectively.

\section{The need for reforms to improve the performance of health systems}

13. As part of a continuing process to raise living standards and welfare, all OECD countries are striving to improve the performance of their health systems. Spending on health systems averaged $9 \%$ of GDP in OECD countries in 2006 (OECD, 2008a) and nearly three-quarters of this spending is public expenditure. Moreover, recent work suggests that individuals may value gains in health status as highly as gains in GDP (Murphy and Topel, 2006), yet not all OECD citizens have access to basic health insurance and health status is distributed very unevenly across populations (De Looper and Lafortune, 2009). Recent analysis of OECD health data, using regression analysis and data envelopment analysis, suggests that there is significant scope to improve efficiency, for example, in most if not all OECD health systems (Joumard et al., 2008). The work of the OECD's Health Care Quality Indicators (HCQI) group shows persistent gaps in health care outcomes across countries. It is such shortcomings in the performance of health systems which form the basis of the case for health system reforms.

14. It is necessary to assess the 'performance' of health systems - and their reforms - against the main objectives of health policy. OECD work has long focused on access, quality, responsiveness, sustainability, equity and efficiency. This paper recognises all of these goals - although to keep the discussion manageable in the exposition which follows, 'quality', 'responsiveness' and 'sustainability' are usually subsumed under 'efficiency' and 'access' is usually subsumed under 'equity'.

15. Achieving efficiency, will involve both maximising a weighted sum of health improvements and responsiveness for given spending (achieving value for money) and finding the 'right' level of health expenditure versus spending on other goods and services. The latter usually manifests itself as a problem of public cost containment - although it is also possible for governments to spend too little on health care. Unfortunately, it is difficult to measure either of these concepts of the efficiency of health systems, because of the difficulty in measuring outcomes and their value.

16. Equity goals may vary somewhat across countries but there is widespread agreement about pursuing equity in access to basic health care across populations and about pursuing fairness in paying for basic health care and providing financial protection against catastrophic medical care costs, especially for the poor. There is also growing agreement about the importance of pursuing equity in health status itself across populations, since good health is necessary for citizens to flourish. 


\section{The design and implementation of health system reforms}

17. The design and implementation of health system reforms can be thought of as a circular process of improvement (Figure 1). First, evaluation of a health system's performance by the government or by other interested parties is likely to reveal shortcomings in the efficiency or equity of the system. Secondly, this diagnosis may lead the government or other interested parties to design and propose structural reforms aimed at tackling the shortcomings. Thirdly, if the government is convinced by the case for reform and has adequate leadership and political authority to drive the process forward, it may seek to introduce legislation, regulation or other policy measures, paving the way to reforms. Fourthly, legislation or regulation must be implemented by the agents concerned with the financing of the health system or with the delivery of services, if performance is to be improved. Finally, the circle will be completed if the impact of the reforms on the performance of the health system is subject to evaluation. There will be interdependence between the successive stages of reform - each can be thought of as a necessary but not in itself a sufficient condition for a successful outcome. Note that this framework allows for consideration of two different questions: what are the determinants of success in the process of health system reforms; and what are the determinants of success in the outcomes? It is possible to implement well the 'wrong' reforms and it is possible to fail to implement well the 'right' ones. Meanwhile, there may be only a limited capacity for reform and any of the four stages may act as a bottleneck in the process.

\section{Figure 1. The process of reform design and implementation in a health system}

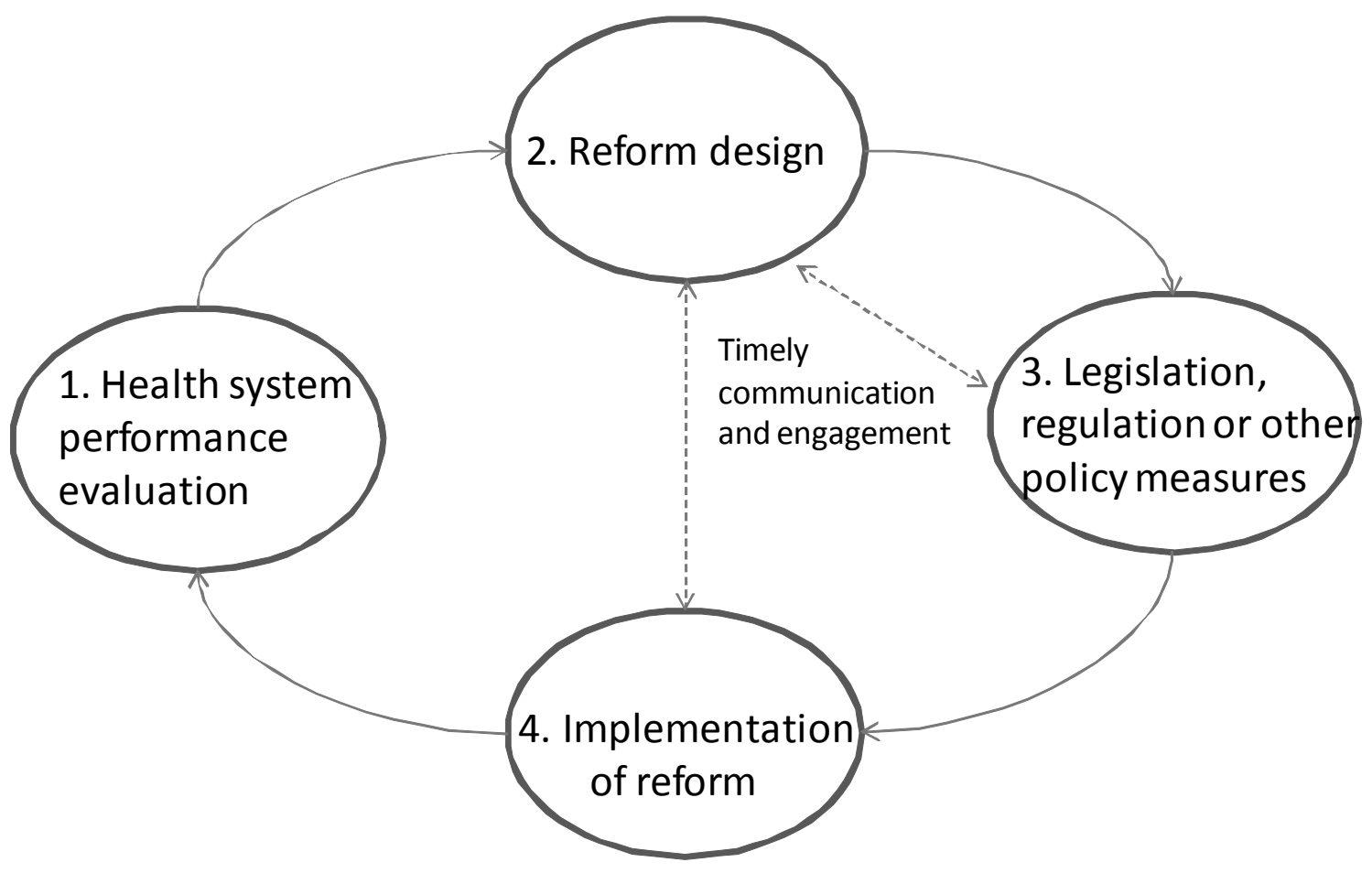

Source: adapted by the author from Nutley and Smith, 1998.

18. It is unknown for a set of reforms to fix all of the problems with a health system at one go. Moreover, it is quite common for there to be unintended or unanticipated side-effects of reforms - which call for further structural changes to be made. In addition, in the longer term, changing expectations among 
consumers, changing technology or changing resources may precipitate a case for further reforms. For these reasons, it is appropriate to think of the process of reform and implementation as potentially continuous.

19. Carolyn Tuohy has written an illuminating analysis of the process of health reforms from a political science perspective. It is based mainly on reform experience in recent decades in three countries Canada, the UK and the US (Tuohy, 1999). She emphasises the difficulties which face significant structural reform of health systems. Only rarely is there sufficient mobilisation of political will and authority outside the health arena, together with a set of appropriate policies, to drive through successful change to the parameters of the health system. Established interest groups can frequently thwart or de-rail such changes. Tuohy draws attention to the many occasions on which health reforms were not attempted (as in Canada in the 1990s) or failed (as in the US in 1993). However, occasional 'windows of opportunity' open for significant reforms.

20. Once established, the parameters of the health care system generate a distinctive logic that tends to govern the behaviour of the participants in the system until the parameters are changed again. The system may change dynamically under its own logic but only minor, government-inspired reforms are likely to be possible during these periods. Hence, Tuohy has entitled her book Accidental Logics.

21. Tuohy also emphasises the historical uniqueness of each health system and the 'path dependency' which governs its evolution. From an international perspective, policies cannot be uprooted from their national context - although knowledge of comparative policies can be an aid to the judgement of national reformers.

22. Nevertheless, as Docteur and Oxley (2004) have shown, many OECD countries have accumulated a significant history of health-system reforms. One well- travelled path has been the introduction of successive extensions to health insurance coverage for different groups in the population over many years, culminating in the achievement, in most OECD countries, of universal health insurance, usually with a significant element of compulsory insurance and significant redistribution of income. That has frequently led to problems with cost containment, because of the lowering or removal of financial barriers to access and the moral hazard engendered by health insurance. That, in turn, has encouraged the introduction of cost control measures by governments, which have sometimes had distorting side-effects on prices or volumes - and presumably on micro-efficiency. Despite such measures, costs have generally continued to rise because of technological improvements in medicine and the ageing of populations. The ongoing search for cost containment, as well as for the more elusive value-for-money, has led to a quest for improvements in micro-efficiency in health systems. This continues in all OECD countries.

\section{Factors which can help or hinder health system reform}

23. Much has been written about health reforms but little about the factors which help or hinder such reforms - especially from a prescriptive point of view. Although Carolyn Tuohy (op. cit.) describes her account of health reforms as a work of analysis, not prescription, she does draw two policy conclusions in her final remarks. The first is that because political 'windows of opportunity' to secure structural changes to health systems are rare, would-be policy makers should work out their policies in advance and strike quickly when the political opportunity arises. Secondly, between these windows of opportunity, any reforms should 'go with the grain' of the health system. In other words, acts of periodic boldness should intersperse long periods of ongoing prudence. The problem, of course, is in identifying when such a window might open.

24. Schieber (1995) has reviewed the 'preconditions' for health reform, drawing on experiences from OECD countries. Most of his article is concerned with evidence on the institutional determinants of 
the performance of OECD health systems, rather than with the determinants of success in the process of reforms. Also, his advice is aimed at developing countries rather than OECD countries. Nevertheless, he identifies a number of factors which should assist reforms in any health system, including: the availability of information and research on the performance of health systems; various institutional factors which support good governance (such as a strong tax system); political leadership, especially at the top of government; and technical competence among the staff charged with implementing reforms.

25. A recent OECD paper prepared for the Making Reform Happen project has suggested a list of factors which may improve success in realising reforms across different policy areas in the economy under four broad headings:

- The existence of appropriate institutions to support reforms from decision to implementation.

- The impact on and reactions of those affected by the reforms.

- Reform agendas, timing and interactions across different policy areas.

- The role of evidence and international organisations to sustain reforms.

26. The remainder of this section draws on this paper and on the literature cited above, to suggest a set of hypotheses about the factors which help or hinder health reforms. For expositional purposes the analysis below is organised under headings which more-or-less follow the four stages in the reform cycle set out in Figure 1, above:

- The availability and use of information, evidence and analysis about the performance of the health system and about the ways performance could be improved.

- Political leadership and the political possibilities for the government (or governments) to promote reforms, introduce legislation and secure commitment or cooperation from other stakeholders in the system.

- The use of incentives - both sticks and carrots - to align the motivation of the main actors in the system with the objectives of policy.

- The availability and use of resources to purchase improvements and 'oil the wheels of change'.

27. To some extent, these hypothesised factors will be exogenous to the health reform process. For example, policy makers concerned with health system reform are unlikely to be able to alter the constitution of a country or change the growth rate of its GDP very much, both of which are often clear constraints on the prospect of health reforms. However, to some extent these hypothesised factors will be amenable to change - that is they will be open to the exercise of good governance. For example, political processes can be used to win over the opponents of reform and money can be raised to meet the costs from within available resources. An attempt will be made below to identify which of the hypothesised factors will be open to influence.

\section{The availability of information, evidence and analysis}

28. Many of the problems faced in managing and reforming health systems arise from the asymmetries of information which exist between patients and providers and between governments, 
managers and providers. Health professionals hold much of the knowledge about the benefits or potential benefits of health care. Insurers, governments and managers tend to be knowledgeable about the costs. Insured patients may be ignorant about both the benefits and the costs.

29. Accurate diagnosis of the performance shortcomings in a health system is a necessary prerequisite for successful reforms. In the case of some problems - such as the proportion of the population lacking health insurance - the relevant data are fairly easy to obtain. Similarly, there is, in the majority of OECD countries, a significant body of evidence and analysis on the distribution across income groups of access to a variety of health services (OECD, 2004, Chapter 3; and De Looper and Lafortune, 2009). Diagnosis of efficiency failings is much more difficult, because of the lack of health system outcome measures, mentioned above. Perhaps as a result of this, it is possible to identify occasions when the arrival of new outcome data has transformed perceptions of the efficiency of a health system and has helped to precipitate reforms as a result. For example, until the late 1990s, British policy makers and OECD observers believed that the health system in the UK performed well. Health status was about average for a Western European country whereas the health expenditure share of GDP was significantly below average. The combination of average health status and low spending was attributed to high efficiency in the National Health Service (NHS) and calls to increase health spending above small annual increases were rejected by successive governments. However, towards the end of the decade, new, comparative, European cancer-survival data - arguably a reasonable measure of a health outcome - became available, which suggested that, at least in the case of cancer services, Britain's health services were performing poorly compared with those in most other Western European nations. It also became evident that waiting times for elective surgery were much longer in the UK than in most other European countries. The resulting shock to perceptions was followed by the government announcing a major 'NHS Plan' to reform the delivery of health services, together with a large and sustained increase in spending on the NHS. In a reversal of the previous stance, the government stated at the beginning of 'the NHS Plan' that, "In part the NHS is failing to deliver because over the years it has been underfunded" (Department of Health, 2000).

30. At the next stage in the reform process, success in designing reforms can sometimes be aided by appointing a commission or group to diagnose problems in the system and to propose solutions. Two examples are the Beveridge Report in the United Kingdom (UK, 1942) which led to the setting up of the NHS and the influential Dekker Commission (1987) in the Netherlands which has inspired a process of structural reform in the Dutch health system over the last two decades.

31. Ideally, the making of health policy should be 'evidence-based' - or, at least, informed by evidence to the extent that is feasible. Unfortunately, the lack of outcome measurement, already mentioned above, together with a lack of evaluation of many reforms, means that the evidence-base for health reforms is deficient, especially when it comes to identifying ways to improve efficiency. That, in turn, allows competing ideologies to continue to flourish both within and across countries about the best ways to achieve efficiency - for example, by the public-service (Beveridgean) model or by regulated markets (as in the US) for insuring for and delivering health care.

32. Nevertheless, there is a growing international literature on alternative ways to finance and deliver health services which can be used to inform the judgements of policy makers. On the whole, it is easier for the designers of reforms to follow well-worn paths. For example, many OECD countries have adopted versions of the Bismarckian model of national health insurance, which was first introduced in Germany in 1883. Similarly, a number of countries - including, most recently, Turkey (see below) - have, following an international inquiry introduced variants of 'family practitioner' services, with gatekeeping - a longestablished model for delivering primary health care in some OECD countries (OECD, 2009b). This has not prevented reformers from introducing some relatively innovative arrangements - such as 'internal markets' for public hospital care in national health services and regulated competition among health insurance funds within national health insurance schemes (Docteur and Oxley, 2004). 
33. It is desirable to consider at the design stage whether reforms are politically feasible and implementable (see below) with a view to building-in features that are likely to improve the viability and acceptability of the reforms. It is also desirable, if possible, to subject prospective reforms to cost and to benefit-cost analysis and to estimate their distributional consequences. The first is needed to establish the affordability of the reforms or the need to find additional resources. The second is needed to check that the reforms will make the best possible use of resources. The last is desirable to help spot who will be the winners and who will be the losers from the proposed changes - information that may be vital for informing the political process (see below).

34. Finally, evaluation of the realised benefits and costs of reforms - preferably by independent agents - is vital if policy makers are to learn from experience. It is desirable to set up such evaluation in advance to establish a baseline before the changes occur. It is also desirable to focus on measuring outcomes to the extent that is possible. The Netherlands provides a good example given their willingness to shine a spotlight on the outcomes of their recent reforms.

\section{Political leadership and political possibilities}

35. Successful structural reforms will require the exercise of political power or persuasion to propel the reforms through their legislative and implementation stages. As has been mentioned above, Tuohy (1999) has concluded that it is only rarely that sufficient mobilisation of political will and authority is available to make structural reforms to OECD health systems. However, it seems likely that OECD countries differ somewhat in their capacity for health reforms because political institutions differ in the extent to which they support the status quo or changes to the status quo, as the case may be.

36. In the past, some important health system reforms in OECD countries have been introduced by unelected governments. For example, following inconclusive deliberations in the Netherlands about compulsory health insurance over the four decades prior to World War 2, social health insurance was introduced abruptly to a large part of the Dutch population by the German occupation forces in 1941 (Blanpain et al., 1978). National health insurance was introduced in Korea by military dictatorships between 1977 and 1988. However, under current, democratic circumstances, OECD governments will require not only a popular mandate but also the ability to win votes in their legislatures to carry out important health reforms.

\section{Political leadership}

37. Political leadership is likely to be an essential ingredient in securing successful structural reforms to health systems. Leadership will certainly be required by health ministers. However, the explicit or tacit support of Prime Ministers or Presidents is generally required to secure overall political legitimacy for major health reforms and to help in securing public resources. The 'Great Society' reforms which introduced Medicare and Medicaid to the American health system in 1965, were initiated by President Lyndon Johnson following a Democratic landslide in 1964. The major reforms to the British NHS, which introduced an internal market in 1992, were initiated by Prime Minister Margaret Thatcher during her third term in office. More recent examples of political leadership in health reforms are covered in some of the 5 case studies discussed below.

\section{Political possibilities: legislation and regulation}

38. Opposition can be expected to major reforms to any health system. In the context of the lack of comprehensive reforms to the American health system, Fuchs (2009) has reminded us that Machiavilli wrote in 1513 that, "There is nothing more difficult to manage, more dubious to accomplish, nor more doubtful of success... than to initiate a new order of things. The reformer has enemies in all those who 
profit from the old order and only lukewarm defenders in all those who would profit from the new order". More recently, an important political theory has been advanced which identifies variation in the number of 'veto players' across countries; and the ideological distance between veto players; as two critical determinants of variation between countries in the capacity for reform (Tsebelis, 2002). 'Veto players' are political actors whose agreement is required for policy changes to happen. Tsebelis argues that the United States, for example, has many veto players whereas Britain has only one ${ }^{1}$. It has already been argued in this paper that ideologies about health care institutions and their reform can vary within and across countries partly because of uncertainty about the impact of alternative institutions on health outcomes and satisfaction.

39. Many OECD countries - including those with federal constitutions - split the responsibility for funding and providing health services between central and local government. Tsebelis argues that federalism increases the number of veto players. He also argues that the possibility of calling referendums adds to the number of veto players.

40. Unitary states with constitutions that allow a central government with a popular mandate to control the legislature and the health system, would seem to come out as having greater reform capacity than states with many veto players under this theory. However, in a number of such countries, the health system has become a 'political football' on some occasions, with successive governments of different political persuasions introducing competing reforms which reverse some or all of the changes introduced by their predecessors. Nations where a long period of negotiation and compromise between a number of veto players has preceded reforms, seem likely to make changes which have wider ownership and, consequently, greater sustainability when there are swings in the political pendulum.

41. Another important argument relates to the fact that the beneficiaries of reform are often diffuse whereas the losers are concentrated. Policies to improve efficiency in health care delivery may be resisted successfully because the beneficiaries (patients) are diffused whereas the losers (providers) are concentrated. However, policies which involve improving, say, access to health insurance may be easier to introduce - partly because there is widespread altruism among voters when it comes to social provision of access to health care; and partly because it is generally in the long term interests of providers to cooperate in any expansion of the market.

42. A further issue is that some health policies can fall under the responsibility of different ministries and disagreements can arise between them. When it comes to the level of public spending on health, there is almost invariably tension between the Ministry of Finance and the Ministry of Health. When it comes to disease prevention involving changes in lifestyles, there is generally a need for several ministries, such as those for transport, food and agriculture, and the environment to cooperate in the design of new policies. In these cases, successful reforms generally involve one ministry accepting budgetary costs for certain benefits which accrue to the clients of another ministry.

43. Despite Tuohy's advice about striking 'while the iron is hot' it may sometimes be necessary to invest in protracted discussion and negotiation about reforms. For example, in the Netherlands, after important reforms to the health system were proposed by the Dekker Commission in 1987, involving the introduction of a single national health insurance system embodying regulated competition, agreement could be reached only about incremental changes in the first instance. It was nearly 20 years before the final decisive legislative step was taken towards a version of managed competition, in 2006. Moreover,

1. Just considering the legislative process, the House of Representatives, the Senate and the President all have to approve legislation (subject to over-rides) in the United States; only the House of Commons is relevant for financial matters in the United Kingdom. 
implementation of these reforms is still underway. This may be an alternative strategy when political 'windows of opportunity' for rapid strategic reforms fail to open. In other areas of discussion of the 'Making Reform Happen', a distinction has been drawn between open reforms, and 'reform by stealth' (e.g. OECD, 2009). Reforms by stealth involve making apparently technical changes to a system, perhaps over many years, which end up being as significant as a major structural reform. However, it is a strategy very vulnerable to being reversed if the political mood swings, and can lead to incoherent, semi-finished reforms. The Dekker reform is perhaps an example of such a reform by stealth which turned out successfully in the end.

\section{Political possibilities: implementation}

44. Further problems can arise at the stage that steps are taken to implement reforms. If the insurers and/or providers are in independent hands, negotiations with such private parties may well be required if implementation is to be successful. Even if the health insurers and/or the providers are in public hands, there may well have been 'provider capture'. In particular, there can, under any ownership arrangements, be formidable opposition to reforms from health professionals, especially the doctors, if they perceive that their professional freedom or economic interests are threatened.

45. A simple, but useful, model of the political structure of the health care system distinguishes between three main interest groups: the consumers; the administrative rationalisers; and the professional monopolists (Alford, 1975). The consumers often represent the weakest of these groups and the professional monopolists - led by the medical profession - often represent the strongest.

46. The power and position of the medical profession (which is shared to a lesser extent with other health professions, such as nursing) arises from several characteristics of the health care market including: the importance of medical care itself to the population; the impaired decision-making ability of patients when they are sick; the asymmetry of medical knowledge between patients and doctors; and the legal monopoly that doctors have been granted in the supply of medical care. Medical care is not a service which can be withdrawn or disrupted without great risk to sick individuals and society. Sick people are peculiarly vulnerable as consumers. The superior knowledge of doctors is acquired following a long theoretical and practical training. Because of the risk of sub-standard practice, the medical profession has been granted a legal monopoly in the supply of medical care. Other professions may share some of the economic characteristics of medicine but few if any possess all of these attributes.

47. This state of affairs has important economic and political consequences which need to be taken into account when reforms to health care are contemplated - especially those involving attempts to improve the efficiency of the delivery of health care. First, the asymmetry of knowledge means that doctors have to act as agents for their patients. Members of the medical profession are committed to act ethically - that is in the interests of patients - when they supply care. As a consequence, medical sovereignty often replaces consumer sovereignty in the demand for health care. Secondly, also as a result of the asymmetry of knowledge, the medical profession has acquired the right to a large measure of clinical freedom and the power of self-regulation in most if not all OECD countries. Indeed, it could be said that there is an implicit contract between the medical profession and society under which the medical profession undertakes to behave ethically in exchange for the right to clinical freedom and self-regulation ${ }^{2}$.

2. Self-regulation has, however, come under review in some OECD countries in recent years because of isolated scandals and a growing understanding of the scale of medical errors - although the latter should probably be seen mainly as a result of system failures (see Mattke, S, 'Monitoring and improving the Technical Quality of Medical Care: A New Challenge for Policy Makers in OECD Countries', Chapter 2 in OECD, 2004. 
Third, doctors are generally the leaders in the clinical teams which increasingly characterise the delivery of modern medical care.

48. The medical profession has acquired exceptional economic power as a result of: the lengthy training required to become a doctor; the leading role that doctors play in decisions about care in relation both to consumers and to members of related health professions; and the legal monopoly that doctors have been granted over the supply of medical care. This is bolstered by the fact that the profession is generally well-unionised and can often control or influence entry to its ranks with a view to maintaining the scarcity of doctors. True, when it comes to setting the terms and conditions for publicly-funded medical services, the government or its agents also wield considerable negotiating power. In these circumstances, there is bilateral monopoly. Nevertheless, doctoring is often the best-paid profession in OECD countries, although the ratio by which average medical remuneration exceeds the average wage varies greatly across countries (OECD, 2009a).

49. The profession also has high status and significant political power. This is especially apparent when, as often happens, the consumers side with the doctors in opposing reforms which cut across the profession's interests. In general, consumers trust physicians more than they trust politicians ${ }^{3}$.

50. As a consequence of its political and economic power, the medical profession may have the ability to impeded structural changes to the health system with which it disagrees. In particular it may resist reforms aimed at improving efficiency if they are perceived as affecting adversely the profession's clinical independence or its economic interests. That is not to say that doctors will oppose all attempts to improve efficiency. Indeed, as a mission-driven and science-based profession, doctors can be relied upon to take the lead in supporting measures - such as innovations - which demonstrably improve the quality of care. They may also be persuaded of the need to do more with less, or to make professional changes and sacrifices, if the case is sufficiently convincing and/or there are suitable incentives (see below). All of this suggests that timely engagement with the medical profession will often be a prerequisite for successful reforms.

51. More widely, both at the legislation/regulation and implementation stages, reforms are more likely to succeed if a realistic assessment is made of any opposition to the reforms that is likely to arise. It may be that the government has sufficient power to override such opposition. If not, it will be necessary to embark on timely communication and engagement with the interested parties with a view to persuading them of the case for change (see Figure 1). The application of incentives and the availability of resources to 'oil the wheels of change' may aid such a process (see below).

52. The quality of public administration is likely to help to determine the success of any reforms. Moreover, the chances of success may be improved in countries where the role of the Ministry of Health is focussed on 'steering' rather than 'rowing' - that is on guiding and regulating the health system at arm's length rather than on 'hands on' involvement in the provision of services (Osborne and Gaebler, 1992). Otherwise, the Ministry of Health may face an internal conflict of interest. The quality of public management - such as hospital management - will also be important where provision is in public hands. Managers will have a particularly tricky task to perform if they are charged with implementing reforms which are unpopular with the clinicians. Finally, a trap lies in wait for zealous reformers in unitary states

3. For example, in the UK, the most recent biennial survey of public attitudes towards conduct in public life, by the Committee on Standards in Public Life, found that the proportion of respondents who said that they would trust government ministers and members of parliament to tell the truth were $27 \%$ and $26 \%$, respectively. Trust in family doctors to tell the truth was $94 \%$ (UK, 2008). This survey was conducted before the scandal over the expense-claims of members of parliament erupted in 2009 in the UK. 
which have control over the management of the health system. Wave after wave of reforms can lead to 'reform fatigue' among managers and clinicians alike.

\section{The use of incentives and disincentives}

53. Successful reforms, especially those aimed at improving microeconomic efficiency, often embody changes to the monetary and non-monetary incentives facing the main actors in the health system. They may involve the judicious use of changes in cost-sharing among consumers. They may involve changing the incentives and opportunities facing health insurers. They may involve modifications to the payments and other incentives facing providers. These are large subjects which have generated a considerable literature. Reviewing this literature is outside the scope of this paper. Suffice it to say, that although much is known about the effect of different payment and incentive systems on the volume of services demanded and supplied in various settings, less is known about the effects on the quality of care, because of the lack of health outcome and quality measures.

54. Financial incentives may also be used by central governments to help persuade other entities, such as state or local governments, to cooperate in health system reforms, when such entities have significant responsibilities for health care. For example, central governments may make grants available to local governments when they adopt certain reforms, or they may make matching funds available when local authorities incur expenditure on meeting national targets for the provision of certain services.

\section{The availability of resources}

55. The availability of resources can help to determine whether reforms are successful or not. There are generally net costs in the case of reforms which are designed to promote access, or equity of access, to health services. The design of such reforms needs to take careful account of affordability. Most countries which have achieved universal health insurance have done so step by step starting, many decades ago, with groups in the population which are best able to afford voluntary or compulsory health insurance and ending, more recently, with those requiring large subsidies. However, in the case of Korea, affordable, compulsory national health insurance was achieved for the whole population in 1989, at a relatively early stage in the country's economic development, by setting the average cost-sharing level originally at about $50 \%$ of the average price of insured health care. Similarly, many countries which have established universal public insurance for health care have discovered that there continue to be problems concerning unequal access to public services across geographical areas in the country. That is partly a legacy of previous inequities in health expenditure, staffing and buildings across different areas which tend to persist. In such circumstances, it is very difficult, politically, to 'level down' rather than to 'level up'. Hence, it can require either substantial resources or considerable time to achieve equal access for equal need across all areas in the country.

56. In the case of reforms which are designed to promote micro-efficiency, there may well be net savings to be reaped in the long run. However, it may well require an investment of resources in advance to allow such savings to be realised. For example, in view of the fact that labour costs predominate in health care, many reforms aim to raise the productivity of staff. However, it may require a rise in pay rates or other monetary rewards to persuade staff to change their existing working practices. The British National Health Service Act of 1946 was only passed following 18 months of acrimonious negotiation between the Health Minister, and the medical profession which ended with substantial pay increases. ${ }^{4}$

4. Later, the minister remarked famously that, in order to broker the deal with the doctors, he had "stuffed their mouths with gold". 
57. Similarly, investment in information technology might save some labour costs in the long run but it will almost certainly require a significant investment in hardware, software, training and organisational change upfront to achieve such savings.

58. Clearly, the reform agenda must take account of resource availability. Faster economic growth can help the pursuit of both equity and efficiency if it is combined with the right policies. However, there is evidence from some health systems that growing resources can make actors relax whereas shortages can be a spur to efficiency (fluctuations in productivity in Finnish health centres in the 1990s seem to fit this pattern - see OECD, 2005b). In the absence of growth or in the context of slow growth, it may be necessary for the promulgators of reform to find innovative ways to raise efficiency. There is also the 'difficult' possibility of reallocating resources to health from other areas of government spending.

\section{Case studies}

\section{Finland}

59. The Finnish health system resembles those in other Nordic countries by offering universal coverage of a comprehensive range of health services, by being funded mainly through taxation, and by relying mainly on public provision of care. The health system is both more decentralised and more mixed in its funding than other Nordic countries. Local governments in the shape of more than 400 municipalities (415 in 2008) play a leading role both in the financing and in the provision of care. There is, however, some cooperation between municipalities over care. For example, hospital services are concentrated in 20 districts which are formally under the control of the municipalities.

60. The OECD review of the Finnish health system was published in 2005 (OECD, 2005b). In its assessment of the performance of the system, the OECD concluded that it performed rather well. The main problems were long waiting times for many services, such as appointments with general practitioners and elective surgery. Also, it was noted that many municipalities felt that hospital funding was out of control and that there were efficiency concerns about the degree of decentralisation in the system. The report reviewed a number of reforms, some of which were ongoing and some of which were only beginning at the time of the evaluation. Two of them appear to be of particular interest to the project on effective ways to realise health reforms: the National Health Project and the Project to Restructure Municipalities and Services.

61. The National Health Project (the National Programme for Safeguarding Health Care) lasted from 2001 to 2007. It can best be described as a broad collection of incremental reforms. Probably the most important targets of the National Health Project were to decrease the variations in treatment rates across the country and to decrease excessive waiting times for appointments and treatments. The former were tackled by introducing clinical guidelines on what preventive and curative treatments should be offered for the principle causes of illness. These were developed on the basis of earlier and ongoing work by the Finnish Medical Society, Duodecim, which has created an electronic database of evidence-based medicine which can be accessed both by physicians and patients in Finland. The latter took account of the guidelines, where appropriate, and were tackled by setting targets for maximum waits of 3 days for a patient to see a primary care professional, 3 weeks for an outpatient appointment and 3-6 months for recommended hospital treatments, including elective surgery. These targets were reinforced, as necessary, by extra funding (50\% state, $50 \%$ municipal), by formal follow-up evaluation reviews and by conditional fines (for the poorest performers). They were introduced during a period when per capita health expenditure was rising fairly briskly.

62. An evaluation of the National Health Programme was commissioned by the Ministry of Social Affairs and Health, in 2008. Both successes and failures were reported. The best results were seen in the 
actions aimed at improving access to services. The number of patients waiting over 6 months for surgery had fallen from 60,000 in October 2002 to 34,000 by August 2005 and to 1,700 by the end of 2008. About $90 \%$ of health centres were achieving the target of seeing a primary care professional within 3 days. However, waiting times to see a primary care physician had increased in some parts of Finland because of difficulty with recruitment. The guidelines seemed to have had a positive effect on access and equity of access to treatments. Treatment rates for some overprescribed operations such as cataract surgery had decreased and treatment rates for some under prescribed orthopaedic operations had increased.

63. The success of these elements in the reforms may be attributed to a number of factors. First, in the case of the guidelines for uniform clinical care, the guidelines had the advantage of being 'owned' by the Finnish medical profession which ensured both their authority and their clinical acceptability. In the case of the waiting times reductions, they were popular with patients, acceptable to the medical profession when they were motivated by the guidelines, incentivised by financial sticks and carrots and were funded by a period of steady growth in health expenditure.

64. The Project to Restructure Municipalities and Services was set up in May 2005, just before the OECD report was finalised and was still ongoing at the time this paper was written in 2009. The OECD report had debated the pros and cons of extreme decentralisation of the governance of health care of the kind found in Finland and had recommended that some consideration be given to the regionalisation or centralisation of hospital services on efficiency grounds. The aim of the Project, which covers all the responsibilities of the municipalities, is to increase the efficiency and productivity of municipalities and the services they provide. A striking feature of the Project is that it involves not only representatives of appropriate ministries and local authorities but also representatives of the opposition parties. This reflects a tradition of striving for consensus in Finnish politics.

65. After consideration was given to three different models for reforming local government in Finland, it was decided, in 2006, to focus on a model for encouraging voluntary mergers between municipalities and services, with the help of financial incentives. Research has suggested, for example, that the minimum efficient population required to support a health centre is $20-30,000$ people. Yet over 250 municipalities have less than 6,000 inhabitants. It is also believed that it is more difficult to secure continuous medical cover and more difficult to recruit staff to small health centres.

66. The Project has had some success in that the number of municipalities has decreased from 432 in 2005 to 348 in January 2009 and further reductions have been announced. The largest government party, the Centre Party, has been in the driving seat. However, for historical reasons, small municipalities in rural areas have been Centre Party strongholds. Not surprisingly, perhaps, the Centre party suffered considerable setbacks in the local elections in October 2008. This outcome may lead to a less radical approach being taken to the final reforms.

67. The progress which has been seen with this Project seems to illustrate how difficult it can be to agree reforms which attempt to trade-off assumed efficiency gains against other principles, such as the preservation of local democracy and the convenience of local access to services. However, a gradual, consensus-based and incentive-based approach seems to be working to bring about a more efficient level of de-centralisation in Finland.

\section{Korea}

68. Korea achieved universal health insurance in 1989 following a step-by-step extension of social health insurance across different groups in the population, under successive military governments, starting in 1977. By adopting Bismarckian social health insurance arrangements, Korea followed a well-trodden path, rather like that of Japan, some decades earlier. The relatively rapid achievement of universal health 
insurance was aided by a high rate of economic growth in Korea. However, the insurance coverage is neither broad nor deep and out-of-pocket payments still accounted for $36 \%$ of health expenditure in Korea in 2006 - one of the highest ratios in the OECD. This high level of cost sharing made compulsory insurance more affordable, not least because it is likely to have moderated demand. On the supply side, the majority of providers are private. Consequently, the Korean health system retains many of the characteristics of a private market, despite the universal applicability of social health insurance.

69. The expectation of life at birth is above the level that might be expected given that health expenditure per capita and as a share of GDP (at $6.4 \%$ in 2006) is below the level that might be expected for a country with Korea's GDP per capita (OECD, 2007).

70. Following the transition to democracy in Korea in 1988 and the coming to power ten years later of a progressive President interested in social protection, two structural reforms were introduced to the health system in July 2000 (OECD, 2003). One was initially more successful than the other. The 'Integration Reform' brought together about 370 insurance societies in one single, 'National Health Insurance Corporation' (NHIC) with the aim of increasing both equity and efficiency. This reform allowed contribution rates to be unified across the population. Rates had previously been different across the population although benefits were the same. The reform also enabled there to be national pooling of risks, the exploitation of economies of scale and the creation of a monopsony in public purchasing of health care.

71. The 'Separation Reform' brought about specialisation in prescribing (by physicians) and in dispensing (by pharmacists), mainly with the aim of reducing medically unnecessary use of drugs and encouraging efficiency in prescribing. Previously, physicians had been allowed to dispense as well as to prescribe drugs, and had earned significant income from doing so. Pharmacists had been allowed to prescribe as well as to dispense for patients who complained of minor symptoms.

72. The Integration Reform was successful. Integration of contribution rates for employed and selfemployed workers was achieved in 2000, and integration in financial accounts was completed in 2003. Administrative costs had been $6.7 \%$ of total health insurance payments in 2000. By 2004, they had fallen to $4.3 \%$ and by 2007 to $3.3 \%$. The reform allowed the setting up of a Health Insurance Review Agency to audit medical claims and to review the appropriateness and economy of the services provided to the insured population.

73. The Separation Reform seemed to be less successful in the short term, but can be judged to have been a success in the long term. The doctors were strongly opposed to the loss of their dispensing privileges and income. Although the government raised medical fees somewhat in anticipation of the reform, the physicians were not satisfied with the initial level of compensation. There followed several periods of strike action by the doctors, before and after the introduction of the reform, which were met by progressive increases in fee levels. By the time that the strikes had been settled, fees had risen by about $40 \%$. Also, the government had conceded the right for doctors to continue to dispense injections - and about $50 \%$ of consultations resulted in an injection.

74. The steep increase in fees exacerbated a deficit in the National Health Insurance scheme, which in turn necessitated the raising of copayment rates, increases in contributions and other measures. Public spending on health per capita rose by $32 \%$ between 2000 and 2001 and the public health spending share of GDP rose from 2.2 to $2.9 \%$ (OECD, 2007). It is difficult to say how much of this increase was due to the Separation Reform and how much was due to upward momentum in the underlying deficit. Also, some of the fee increases appear to have been clawed back in later years - the public health spending share of GDP was still $2.9 \%$ in 2004 . On the positive side, the aim of separation was achieved and there appear to have been some significant improvements in the quality of prescribing as a result. For example, the proportion of prescriptions including antibiotics decreased from $55.7 \%$ in 2000 to $45.1 \%$ in 2002 and to $29.6 \%$ in 


\section{DELSA/HEA/WD/HWP(2010)2}

2008. And the number of drugs per claim fell from 5.9 in 2000 to 4.5 in 2002 and again to 4.2 in 2008 (Jeong, 2009).

75. Why was one reform initially more successful than the other? Both the Integration and Separation reforms had been informed by international comparisons of health policies and both had been discussed for some time between the government and interested groups in Korea, prior to their introduction. Both had the full backing of the President. The Integration reform had the support both of the rural population and the labour unions. In the case of the Separation Reform, there was also support from civic groups. There had been discussions between representatives of civic groups (patients) and the leaders of the medical profession and an understanding had been reached that there was agreement from the profession for the reform to go ahead. However, it seemed that the then medical leadership was not fully informed of the views of the rank and file among physicians and there was clearly outrage, especially among doctors in training, at the prospect of reduction in their incomes when the reform went ahead. It seems that the government was misinformed about the likely reaction of the doctors and that with hindsight more communication and engagement between the government and the doctors would have been desirable. Partly as a result of this experience, the government has established a Committee for Health Insurance Policy Deliberations which brings together at regular intervals representatives from three major stakeholders - the medical providers, the insured and patient groups, and institutions representing the public interest such as the Ministries of Health and Finance and academics.

76. Among the recommendations of the OECD Review of the Korean health system was a suggestion to improve financial protection in the National Health Insurance scheme by introducing an annual cap on accumulated co-payments for any individual. This reform has gone ahead together with other improvements to benefits, such as adding magnetic resonance imaging and CT scanning to NHI cover (Colombo and Hurst, 2008). Such improvements in benefits were informed by evidence that out-of-pocket payments on medical utilisation in Korea are regressive and that there are inequities in access to cancer care for low-income individuals (Kim, Lee and Hong, 2005). The improvements to benefits have been enabled partly by Korea's high economic growth rate - which averaged 3.9\% between 2000 and 2005, more than twice the OECD average.

\section{Mexico}

77. The Mexican health system has consisted of a large and mostly unregulated private sector and a public sector fragmented into several vertically-integrated social insurer/providers each covering different parts of the population including two large social security organisations covering formally-employed, salaried, private-sector workers and government employees, respectively. There is a quite separate system of State health services for the poor and uninsured which has not been very well funded in the past. Public governance has been split between the Social Security system, the Federal Ministry of Health and the State governments. Until recently, those formally insured represented only about $50 \%$ of the population. Mexico has had one of the smallest public shares of total health expenditure in the OECD area (44\% in 2006). Moreover, public funding per capita has been inversely correlated with indicators of need, such as infant mortality, across geographical areas (OECD, 2005a). As a consequence, access to health care has been very uneven across the population and it was estimated in 2003 that nearly $20 \%$ of the poor (those in the first income quintile) incurred health spending that pushed them below the poverty threshold (OECD, 2005).

78. A major reform, the System of Social Protection in Health, was introduced in 2004 under the leadership of the Ministry of Health (OECD, 2005a). The main element of the reform was a new voluntary health insurance scheme, the 'Seguro Popular' (Popular Health Insurance), which was designed to provide, progressively between 2004 and 2010, coverage for a package of essential interventions for the poor and uninsured. The scheme was financed by separate Federal and State contributions per enrolled family and 
by a small, means-tested premium paid by each family. The fact that Federal contributions depended on voluntary enrolment, gave the States an incentive to promote the scheme and the fact that it was aimed at the uninsured meant that extra Federal resources tended to flow to the States with the lowest public health spending per capita. It was envisaged that the insured would be free to utilise any health care provider, which meant that money would follow the patient and a step would be taken towards horizontal integration of the system.

79. The Seguro Popular has grown quickly since it was first set up. By the end of 2007, 7.3 million families were signed up to the scheme and public health insurance coverage had risen to about $75 \%$ of the target population. The government was planning to increase the budget for the scheme by $31 \%$ in 2009 with the aim of covering 11.1 million families (Bruce, 2008).

80. The success of the Seguro Popular can be attributed to a several factors. The reform addressed a problem - lack of health insurance coverage in the population - the adverse financial and health consequences of which had been well informed by research and international comparisons (Knaul and Frenk, 2005). There was strong leadership from the Ministry of Health and the reform was cleverly designed to avoid opposition by existing 'veto players' by complementing the existing social security system and to incentivise both families and the States to take up the scheme. There was time to pilot the reforms between 2001 and 2003 under the 6-year presidency of Vicente Fox and a realistic, 6-year implementation period was chosen from 2004. The reforms were successfully negotiated both within Congress and with the State Governments. Finally, much emphasis was put on a sustained effort to raise resources both from Federal and State budgets against a difficult fiscal background. However, various challenges remain, including: variability of political allegiances in Congress and across the States; variability in implementation capacity at the State level; and continuing problems with fiscal capacity.

\section{Switzerland}

81. Switzerland has a particular form of universal health insurance. Everybody in Switzerland is required to buy health insurance covering a package of basic health care, with the State subsidising the premiums for the poor. The insurers are private entities but they are not allowed to make a profit on the basic package and they must operate open-enrolment. Citizens have free choice of health insurer and the insurers compete mainly on service and price. The premiums are both flat-rate and community-rated: the rich pay the same rate as the poor. There is a risk-equalisation mechanism which compensates insurers with less favourable risk structures. There is a high level of cost-sharing and direct payments for uncovered services and, at $40 \%$, the private share of health spending is the $5^{\text {th }}$ highest in the OECD area. On the supply side, most hospitals are owned by Cantons and ambulatory care doctors are self-employed.

82. Governance is fragmented. Social insurance is mainly a Federal responsibility. The provision of health care is a Cantonal responsibility. Public health is a joint Federal/Cantonal responsibility. There are 26 Cantons and it has been said that Switzerland has 26 health systems. Also, changes to the law at a national level may be submitted to a referendum at the request of either 50,000 voters or 8 Cantons. Since 1974, at least 9 proposals for changes to the health insurance law have been rejected in popular ballots, all with an overwhelming majority.

83. The OECD/WHO review of the Swiss health system was published in October 2006 (OECD, 2006). Collaboration between OECD and WHO was requested by the Swiss authorities in order to obtain an overview of the health system both from an economic and a public health perspective. It also assured a good acceptance of the report at the national level. This was followed in 2007 by a study comparing the Dutch and the Swiss health care systems, which share some important similarities (Leu, et al., 2007). The aim was to inform the ongoing reform process in both countries. 
84. According to the OECD/WHO report, the level of health status in Switzerland compared well with levels in other OECD countries. There was an abundance of modern medical care and patients were largely satisfied with the services they received. However, these successes came at a high financial cost. At $11.6 \%$, Switzerland had the second highest health expenditure share of GDP in the OECD area and the highest in Europe at the time of the OECD/WHO review. Moreover, the rate of growth of health expenditure had been outpacing the rate of growth of GDP more than had been the case for the corresponding OECD averages (OECD, 2006).

85. Although there was no formal implementation process for the OECD/WHO review in Switzerland, the report is considered to be a reference document in the discussions about further health reforms. The "independent view" of the OECD/WHO experts is seen as an advantage. The report describes 6 types of reforms and makes 23 recommendations. Some of them were already ongoing or only beginning at the time of the evaluation. Two of them appear to be of particular interest for the OECD project on effective ways to achieve policy reforms: the revision process for the Federal health-insurance law (LAMal); and the prevention and health-promotion law project.

86. The last major reform to the Swiss health system was the passage of the LAMal by a narrow majority in a referendum in 1994. That had been preceded by discussions with all stakeholders which had started in 1991. It was this law which introduced important aspects of the present system such as universal health insurance, a uniform basic package of care, State subsidies for the poor, free choice of insurer, community rating of premiums, a risk-equalisation mechanism and the non-profit status of insurers. It was envisaged that cost containment would be promoted by regulated competition among the insurers.

87. The successful passage of the LAMal, which was introduced by a Social Democrat Administration, can be attributed to a growing consensus in Switzerland that all Swiss citizens had the right of protection against catastrophic medical expenses and the right of access to high quality medical care. Also, in many ways the law represented only incremental change. Around $95 \%$ of citizens were already covered for health insurance voluntarily and many of the insurers were already non-profit mutuals.

88. However, whereas the LAMal introduced universal health insurance, it did not seem to succeed in the aim of introducing cost containment through competition between insurers. Health expenditure had continued to grow much more rapidly than GDP. Further reforms had therefore been discussed. In 2003, a market-inspired reform was proposed aiming at increasing competition in the system, but it was rejected by the Parliament. In 2007, a counter-proposal for a single health insurer and income-related premiums was subsequently defeated at a referendum, also. Since 2004, the government has tried to submit to Parliament a set of incremental and market-oriented reforms. Some important legislative changes have been approved as a result and will come into force in 2012, including the introduction of a DRG-based hospital financing mechanism; the possibility to use hospitals in other Cantons and the modification of the risk-compensation mechanism for insurers (to include risk-adjusters based on morbidity data). Reforms which would have introduced more state control have been rejected, at the same time.

89. The project of a federal law on prevention and health promotion had already started at the time of the publication of the OECD/WHO report. The report has probably reinforced the process of reform. A special commission was created in 2006 and it made some recommendations about the legal, financial and organizational measures which would be necessary for the reinforcement of prevention and health promotion in Switzerland. The report of this commission was distributed to members of Parliament and in September 2007, the Federal Council gave the mandate to draft a law on prevention and health promotion. The first proposal was supported by $3 / 4$ of the consulted stakeholders and by a majority of cantons. The draft law will be submitted to Parliament in 2009. Federal leadership, associated with political consensus, is behind the successful progress towards this reform. 
90. Considering the recent discussions about health system reform in Switzerland, especially since the publication of the OECD/WHO report, the following conclusions can be drawn: (1) In general, the main reason for failure/delay in adopting reforms is the lack of political consensus. In Switzerland two opposing ideological groups of equivalent strength coexist at the same time. One group would like to have more state control while the other is in favour of introducing more competition in the health system; (2) The barriers to reform include the fact that the Swiss Constitution gives easily-exercised veto powers to the 26 Cantons and to popular opinion, through referendums; (3)The main determinant of success has been leadership - usually by the Federal government, although this has not been sufficient for the LAMal.

\section{Turkey}

91. The Turkish health system has been undergoing a profound structural transformation since 2003 (OECD, 2009b). Prior to 2003, the system was a combination of a number of social health insurance schemes for different segments of the employed population and their dependents; a national health service providing limited services, free of charge to the population and a social assistance programme for the poor and vulnerable (the 'Green Card'). There were both overlaps and gaps in these arrangements. Moreover, there were serious problems on the delivery side, which meant that even insured people did not always get access to appropriate services. For example, primary care was generally weak, leading to overutilization of crowded hospital out-patient departments. There was also considerable geographical inequity in access to health services.

92. Although health status had been rising in Turkey prior to 2003, life expectancy remained below and infant mortality remained above the levels found, on average, in countries with a comparable standard of living. Only limited data on outcomes are available but comparisons of patient satisfaction with primary health care services across countries, suggest that satisfaction in Turkey was well below the average in a group of 10 European countries (OECD, 2009b).

93. A major set of reforms, 'the Health Transformation Programme' (HTP) was introduced by the newly-elected Justice and Development Government in 2003. The main aims were to unify the existing social insurance schemes and administration of the Green Card under a single insurer which would provide universal health insurance. A purchaser/provider split would be established and autonomy would be granted to public hospitals. A family practitioner service with capitation payments and gatekeeping would be set up throughout Turkey. There would be investment in staff and in information systems. It was planned that the HTP would be implemented during the 10 years, 2003-2013. Although Turkey has a relatively centralised administration, this reform required co-operation across several different ministries with responsibilities in the health sector including the Ministries of Health, Labour and Social Security, and Finance; together with the State Planning Organisation.

94. When an OECD/World Bank team reviewed the Turkish health system and its reforms in 2008, the HTP was half-completed (OECD, 2009b). Universal Health Insurance was achieved in 2008 with the unification of the social security programmes with the Green Card scheme under the Social Security Institute. The new family practitioner services had been rolled out to about $20 \%$ of the population. Public hospitals had been unified under the Ministry of Health and a performance management scheme had been introduced to incentivise staff. The beginnings of a purchaser/provider split had been put in place although public hospitals had not yet gained significant autonomy.

95. As a result of these and other related changes, there has been a large increase in activity both in primary care and in hospitals. Satisfaction with primary care has risen sharply in provinces which have introduced family practitioners. Also, there was a general rise in satisfaction with the health system as a whole in the population. Although health expenditure has risen sharply, it has risen no faster than GDP. The OECD/World Bank Review concluded that although it was too early to make a final assessment, the 
HTP seemed to represent 'good practice' in the development and implementation of major health system reforms and preliminary indications were that it had been successful.

96. Many of the conditions for successful health system reform, which were outlined in the first part of this paper, seem to have been present in Turkey at the launch of the HTP and during the first stage of its implementation. Turkey had informed itself about weaknesses in the performance of the Turkish health system by international comparisons provided, for example, by OECD and WHO data. Reforms of the kind adopted under the HTP, had been put forward under the National Health Policy in 1990, following health reform studies by the Ministry of Health and the State Planning Organisation, and these had been articulated further in the Seventh Development Plan, 1996-2000 (OECD, 2009b). In particular, studies had been carried out of family practitioner services in a number of European countries. However, a major economic crisis in 2000-2001 helped to delay action. It required the election of the Justice and Development Party in 2002 with a strong electoral mandate and the renewal of that mandate in 2007, to kick start and sustain the political momentum for reform. Strong leadership was shown by the new Health Minister. Because of the controversial nature, complexity and likely cost of the proposed reforms, a long period -10 years - was set for steering the reforms through the legislative process and for implementing the results.

97. Under the HTP, there were major reforms to the incentives facing medical specialists and other hospital staff in public hospitals with the introduction of bonus payments under the "performance-based, supplementary payment system'. This linked pay to improved performance by staff. As a result, there were sharp increases in pay rates for doctors between 2003 and 2005; an increase in full-time working by previously part-time specialists in public hospitals; increases in hospital activity rates; apparent increases in productivity per physician; and large improvements in the satisfaction reported by patients with hospital services (OECD, 2009b). The introduction of family practitioner services (in 23 Provinces by October 2008) gave primary care doctors greater pay and autonomy and was associated with a relative shift in consultations away from hospital outpatient departments towards family practitioners and a sharp increase in patient satisfaction with primary care. Meanwhile, strong economic growth in Turkey between 2002 and 2006 helped to fund the extensions to health insurance coverage, the improvements to incentives and the increases in services (OECD, 2009b).

\section{Discussion}

98. Although the five case studies, above, cannot be said to be representative of the OECD area as a whole, and although they could not be said to represent a very large evidence base, they do help to shed some light on the factors associated with the success and failure of health system reforms.

99. All five countries concerned have carried out successful health system reforms recently, despite challenges which seem to vary both with the country and with the type of reform. The depth and scope of the reform varied. Some were more systemic than others, even in the definition phase. Some countries appear to have had less capacity for pushing through health system reforms than others. For example, in Switzerland, the Constitution gives power to many 'veto players' and there is polarisation of political opinion on the best way to carry out health system reforms. This combination of circumstances makes it easy for interested parties to block proposals for reforms in Switzerland.

100. The type of reform - whether it is concerned, say, with equity of access, with cost containment or with microeconomic efficiency - seems also to have a bearing on the challenges which face reformers. Most OECD countries have already achieved universal health insurance (UHI) but in the unrepresentative sample discussed above, only two countries had achieved UHI by the early 1990s. The reforms discussed above brought UHI additionally to Switzerland in 1996 and to Turkey in 2008. Meanwhile, Mexico has made major strides towards UHI with the Seguro Popular since 2004. It seems that movements towards 
UHI have been easier to achieve politically than other health system reforms in most OECD countries although some countries remain an exception. Although there will be losers from such reforms (broadly speaking, those with higher incomes and those with good health) there is widespread altruism in most OECD electorates when it comes to providing everyone in the population with access to basic health care. Also, as has been mentioned above, it is usually in the long-term interests of the professional monopolists and other provider and insurance interests to cooperate in any expansion to the health system.

101. Reforms which deliver cost containment may be more difficult to achieve. Among the countries discussed above, Finland and Korea seem to have achieved admirable control of health expenditure by different means. However, Switzerland appears to be struggling to contain costs. And although Mexico and Turkey have hitherto had comparatively modest levels of health expenditure, the recent improvements to their health insurance arrangements have introduced some uncertainty about the future fiscal sustainability of these improvements to coverage.

102. Most difficult of all may be achieving improvements to microeconomic efficiency. All the countries discussed above struggle with ambiguity about how to achieve microeconomic efficiency because of the lack of measures of health outcomes and quality. This has encouraged ideology to flourish in health policy debates. In addition, it is clear that the medical profession can block reforms - if only temporarily, in some cases - over reforms which challenge their professional freedoms or economic interests. This was noticeable during the implementation of the Separation Reform in Korea, among the case studies discussed above.

103. Against this background, it is possible to identify some of the factors which have helped to bring about success in health system reforms in the countries reviewed above.

\section{Information, evidence and analysis}

104. It is clear that all of the successful reforms summarised above were informed by diagnostic data and analysis which often included international comparisons of health system performance. In particular, Mexico and Turkey utilised national and international health data to help diagnose the shortcomings in access to health services, in financial protection and in health status that were tackled by the introduction of the 'Seguro Popular' and the 'Health Transformation Programme', respectively. International comparisons have highlighted the relatively high level and rate of growth of health expenditure in Switzerland.

105. Similarly, the designs of the reforms summarised above were informed both by national analysis and international comparisons. For example, Finland's successful clinical guidelines were developed with the help of an international medical literature. Turkey's successful family practitioner reforms were developed on the basis of prior studies of family doctor services in a number of OECD countries.

\section{Political leadership and political possibilities}

106. Several of the case studies set out above - especially those for Korea, Mexico and Turkey appear to illustrate occasions when newly elected administrations with strong leadership and strong popular mandates seized political 'windows of opportunity' to make structural reforms to health systems. Perhaps it helped that two of these countries, Korea and Turkey, are relatively centralised states with few veto players. In the case of Turkey, co-ordination across several ministries with responsibilities in the health sector also assisted the passage of the reforms.

107. Three of the case studies set out above, indicate the possibilities for achieving national legislation for health system reforms even when the responsibilities for the governance of the health system rest 
mainly or partly at local government level - increasing the number of veto players. In Finland, the 'Project to Restructure Municipalities and Services' has succeeded in encouraging some voluntary mergers between small municipalities - with a view to bringing about economies of scale - although at the time this paper was written, the final destination of these reforms remained uncertain. Despite the difficulties with national legislation in Switzerland, mentioned above, a major reform to the health system, the LAMal, was passed (if only by a whisker) at a referendum in 1994. In Mexico, potential opposition by some State Governments to the Federal Government's proposal to introduce the Seguro Popular was disarmed by negotiation and engagement. However, variations continue to exist across the States in the capacity to implement the Seguro Popular effectively.

108. The case studies above help to illustrate how important it is to get the medical profession on board before implementing reforms that are aimed at improving the efficiency of health care delivery. As has been mentioned, in Korea, the initial attempt in 2000 to separate the dispensing of pharmaceuticals from prescribing led to a series of strikes by doctors, despite an earlier agreement to this reform by the then medical leadership. The reforms had to be rescued by a very large increase in physicians' fees - suggesting that a high price was paid for the subsequent gains in the efficiency of prescribing. By contrast, in Finland, the introduction of clinical guidelines - with a view to reducing variations in treatment levels and bring down waiting times - was successful because the medical profession had prior ownership of work on standardising treatment protocols. In Turkey, significant prospective increases in doctors pay, combined with new performance incentives, helped to ensure that many individual doctors co-operated enthusiastically with the reforms, despite vociferous opposition from the Turkish Medical Association.

\section{Incentives}

109. Several of the case studies outlined above reveal the use of incentives to support the reform process. Finland put in place both incentives and disincentives to encourage the attainment of waiting time targets, with good results. In Mexico, the Seguro Popular was designed to encourage the poorer States to promote the scheme because Federal transfers would increase with take-up. Turkey, as has been mentioned above, introduced a powerful bonus-payment system which linked pay to performance for staff in public hospitals. It led to a rise in pay rates and it brought about a sharp increase in hospital activity and a large improvement in patient satisfaction with public hospital services. This appears to be an excellent example of meeting the rising demand for services created by improvements to health insurance cover by rising productivity on the supply side.

\section{Resource availability}

110. At least two of the case studies above illustrate the importance of raising resources to help to fund health reforms. In Mexico, the best use was made of limited fiscal capacity by sharing the funding of the Seguro Popular between the Federal Governments and the States. Private contributions to the premiums were also required - albeit at a level that would be likely to be affordable by the poor. In Turkey, the Ministry of Health succeeded in securing an increased share of public spending for the health sector during the early years of the Health Transformation Programme (HTP). It was also fortunate that the introduction of the HTP coincided with a period of rapid economic growth in Turkey. However, it remains a matter of concern that the HTP was only half completed when the world economic crisis started in 2008. This may illustrate one of the risks attending drawn-out, 'big bang' reforms.

\section{Conclusions}

111. It has been suggested in this paper that reforming health systems is a complex, multistage process. All stages in the process - diagnosis, design, legislation/regulation and implementation - must be completed successfully for the reform as a whole to be successful. In particular, successful health system 
reforms will require the co-operation of the professional monopolists who provide health services especially the medical profession.

112. It has also been suggested that the factors which lead to success or failure in health system reforms are to some extent exogenous and to some extent open to management by the governments promoting reform. Various factors which may help or hinder the process of reform have been identified.

113. The gathering of information and evidence seems to be helpful at the diagnostic and design stages of reform. In particular, there is evidence that international comparisons of health system performance and of what works and what does no work in health institutions abroad has been helpful in most countries. The production and publication of a clear diagnosis and a compelling design for a reform has often represented a key, initial step in the process of building a consensus or majority for change.

114. It has been suggested that political 'windows of opportunity' for making major, structural reforms to health systems in democratic countries open only rarely. Strong political leadership - including leadership by Presidents and Prime Ministers - and the exercise of political authority seem to be indispensable for seizing such opportunities. Prior preparation - perhaps by assembling a suitable body to draw up proposals for reform - may help. At other times, reforms will need to 'go with the grain' of the health system. In all cases, communication and engagement between the proponents of reforms and other key stakeholders - especially those holding veto or blocking powers - may help to prevent such stakeholders from exercising their potential vetoes, or from conspiring to reverse the reforms after the next swing of the political pendulum. The skilful use of incentives, to help to align the interests of the key stakeholders with the intentions of the reform, can contribute to success. And securing resources to fund improvements or simply to 'oil the wheels of change' has often been a necessary condition for success.

115. Some of the experiences reviewed above, suggest that there may be tradeoffs between maximising the success and sustainability of health system reforms; maximising the speed at which they are carried out; and minimising the resources that have to be invested in their implementation. To adapt an old management-consultancy adage, it will often be possible to choose any two of these desiderata - but not all three.

116. In view of the relative isolation of health-care systems from one another, and the variety of institutions and ideologies that coexist in the health-care field, there would seem to be a major continuing role for the OECD to provide international data and analysis of what works and what does not work in health policy - and what are the determinants of success in health system reforms. Advancing the collection of health care quality indicators would seem to be a particular priority at the OECD, given the central importance of efficiency to health system performance and the comparative lack of indicators and benchmarks of health care outcomes against which efficiency can be measured.

117. Finally, this paper represents only a preliminary attempt to identify the factors which may help or hinder reforms to health systems. It would be desirable to test the framework offered here in a larger and more representative sample of countries. Further work on this topic is certainly needed. 


\section{REFERENCES}

Alford, R.R. (1975), Health Care Politics: Ideological and Interest-group Barriers to Reform.

Blanpain, J. et al. (1978), National Health Insurance and Health Resources: The European Experience.

Bruce, F. (2008), “More Mexicans to access Health Insurance in 2009” (published online, 03.12.2008).

Colombo, F. and J.Hurst (2002), "Revisiting the OECD Review of the Korean Health System", Osaka Economic Papers, Vol. 58, No. 2, September, 23-54.

Dekker Commission (1987), Willingness to Change, The Hague.

De Looper, M. and G. Lafortune (2009), "Measuring Disparities in Health Status and in Access and Use of Health Care in OECD Countries", OECD Health Working Papers, No 43, Paris.

Department of Health (2000), The NHS Plan. A Plan for Investment: a Plan for Reform.

Docteur, E. And H.Oxley (2004), "Health-System Reform: Lessons from experience", Towards HighPerforming Health Systems: Policy Studies, Chapter 1, OECD, Paris.

Fuchs, V.R. (2009), "Health Care Reform - Why So Much Talk and So Little Action?”, New Engl. J. Med., 360;3; 208-209.

Jeong, H-S. (2009), 'Pharmaceutical reforms: implications through comparisons of Korea and Japan', Health Policy; 93 (2): 165-171

Joumard, I . et al. (2008), "Health Status Determinants: Lifestyle, Environment, Health Care Resources and Efficiency", Economics Department Working Papers, No. 627.

Kim, C.W., S.Y.Lee, and S.H.Hong (2005) "Equity in Utilisation of Cancer Inpatient Services by Income Classes", Health Policy, 72(2), 187-200.

Knaul, F.M. and J. Frenk (2005), "Health Insurance in Mexico; Achieving Universal Coverage through Structural Reform", Health Affairs, 24(6), 1467-1476.

Leu, R.E., et al., (2007), A Tale of Two Systems: the Swiss and Dutch Health Care Systems Compared.

Murphy, K.M. and R.H.Topel (2006), "The Value of Health and Longevity”, Journal of Political Economy, Vol. 114, No. 5, 871-904. 
Nutley, S. and P.C. Smith (1998), "League Tables for Performance Improvement in Health Care", Journal of Health Service Research Policy, Vol. 3, No. 1, January.

OECD (2003), OECD Reviews of Health Systems: Korea.

OECD (2004), Towards High-Performing Health Systems, Paris.

OECD (2005a), OECD Reviews of Health Systems: Mexico.

OECD (2005b), OECD Reviews of Health Systems: Finland.

OECD (2006), OECD Reviews of Health Systems: Switzerland.

OECD (2008a), OECD Health Data, Paris.

OECD (2008b), Making Reform Happen: Project Framework and Plans, SG/MRH(2008)1, Paris.

OECD (2009a), Health at a Glance, 2009

OECD (2009b), OECD Reviews of Health Systems: Turkey.

Osborne, D. and T. Gaebler (1992), Reinventing government: how the entrepreneurial spirit is transforming the public sector, Addison-Wesley.

Schieber, G. (1995), "Preconditions for Health Reform: Experiences from the OECD Countries", Health Policy 32; 279-293.

Tsebelis, G. (2002), Veto Players: How Political Institutions Work, Princeton U.P.

Tuohy, C. (1999), Accidental Logics: the Dynamics of Change in the Health Care Arena in the United States, Britain and Canada, OUP.

UK (1942), Social Insurance and Allied Services (The Beveridge Report), Cmd. 6404, HMSO, London.

UK (2008), Survey of public attitudes towards conduct in public life 2008, Committee on Standards in Public Life. 


\section{OECD HEALTH WORKING PAPERS}

A full list of the papers in this series can be found on the OECD website: www.oecd.org/els/health/workingpapers

No. 50 HEALTH SYSTEMS INSTITUTIONAL CHARACTERISTICS A SURVEY OF 29 OECD COUNTRIES (forthcoming) Valerie Paris, Marion Devaux and Lihan Wei

No. 49 THE CHALLENGE OF FINANCING HEALTH CARE IN THE CURRENT CRISIS (forthcoming) Peter Scherer, Marion Deveaux

No. 48 IMPROVING LIFESTYLES, TACKLING OBESITY: THE HEALTH AND ECONOMIC IMPACT OF PREVENTION STRATEGIES (2009) Franco Sassi, Michele Cecchini, Jeremy Lauer and Dan Chisholm

No. 47 HEALTH CARE QUALITY INDICATORS PROJECT: PATIENT SAFETY INDICATORS REPORT 2009 (2009) Saskia Drösler, Patrick Romano, Lihan Wei; and ANNEX Saskia Drösler

No. 46 EDUCATION AND OBESITY IN FOUR OECD COUNTRIES (2009) Franco Sassi, Marion Devaux, Jody Church, Michele Cecchini and Francesca Borgonovi

No. 45 THE OBESITY EPIDEMIC: ANALYSIS OF PAST AND PROJECTED FUTURE TRENDS IN SELECTED OECD COUNTRIES (2009) Franco Sassi, Marion Devaux, Michele Cecchini and Elena Rusticelli

No. 44 THE LONG-TERM CARE WORKFORCE: OVERVIEW AND STRATEGIES TO ADAPT SUPPLY TO A GROWING DEMAND (2009) Rie Fujisawa and Francesca Colombo

No. 43 MEASURING DISPARITIES IN HEALTH STATUS AND IN ACCESS AND USE OF HEALTH CARE IN OECD COUNTRIES (2009) Michael de Looper and Gaetan Lafortune

No. 42 POLICIES FOR HEALTHY AGEING: AN OVERVIEW (2009) Howard Oxley

No. 41 THE REMUNERATION OF GENERAL PRACTITIONERS AND SPECIALISTS IN 14 OECD COUNTRIES: WHAT ARE THE FACTORS EXPLAINING VARIATIONS ACROSS COUNTRIES? (2008) Rie Fujisawa and Gaetan Lafortune

No. 40 INTERNATIONAL MOBILITY OF HEALTH PROFESSIONALS AND HEALTH WORKFORCE MANAGEMENT IN CANADA: MYTHS AND REALITIES (2008) Jean-Christophe Dumont, Pascal Zurn, Jody Church and Christine Le Thi

No. 39 PHARMACEUTICAL PRICING \& REIMBURSEMENT POLICIES IN GERMANY (2008) Valérie Paris and Elizabeth Docteur

No. 38 MIGRATION OF HEALTH WORKERS: THE UK PERSPECTIVE TO 2006 (2008) James Buchan, Susanna Baldwin and Miranda Munro 
No. 37 THE US PHYSICIAN WORKFORCE: WHERE DO WE STAND? (2008) Richard A. Cooper

No. 36 MIGRATION POLICIES OF HEALTH PROFESSIONALS IN FRANCE (2008) Roland Cash and Philippe Ulmann

No. 35 NURSE WORKFORCE CHALLENGES IN THE UNITED STATES: IMPLICATIONS FOR POLICY (2008) Linda H. Aiken and Robyn Cheung

No. 34 MISMATCHES IN THE FORMAL SECTOR, EXPANSION OF THE INFORMAL SECTOR: IMMIGRATION OF HEALTH PROFESSIONALS TO ITALY (2008) Jonathan Chaloff

No. 33 HEALTH WORKFORCE AND INTERNATIONAL MIGRATION: CAN NEW ZEALAND COMPETE? (2008) Pascal Zurn and Jean-Christophe Dumont

No. 32 THE PREVENTION OF LIFESTYLE-RELATED CHRONIC DISEASES: AN ECONOMIC FRAMEWORK (2008) Franco Sassi and Jeremy Hurst

No. 31 PHARMACEUTICAL PRICING AND REIMBURSEMENT POLICIES IN SLOVAKIA (2008) Zoltán Kaló, Elizabeth Docteur and Pierre Moïse

No. 30 IMPROVED HEALTH SYSTEM PERFORMANCE THROUGH BETTER CARE COORDINATION (2007) Maria M. Hofmarcher, Howard Oxley, and Elena Rusticelli

No. 29 HEALTH CARE QUALITY INDICATORS PROJECT 2006 DATA COLLECTION UPDATE REPORT (2007) Sandra Garcia-Armesto, Maria Luisa Gil Lapetra, Lihan Wei, Edward Kelley and the Members of the HCQI Expert Group

No. 28 PHARMACEUTICAL PRICING AND REIMBURSEMENT POLICIES IN SWEDEN (2007) Pierre Moïse and Elizabeth Docteur

No. 27 PHARMACEUTICAL PRICING AND REIMBURSEMENT POLICIES IN SWITZERLAND (2007) Valérie Paris and Elizabeth Docteur

No. 26 TRENDS IN SEVERE DISABILITY AMONG ELDERLY PEOPLE: ASSESSING THE EVIDENCE IN 12 OECD COUNTRIES AND THE FUTURE IMPLICATIONS (2007) Gaétan Lafortune, Gaëlle Balestat, and the Disability Study Expert Group Members

No. 25 PHARMACEUTICAL PRICING AND REIMBURSEMENT POLICIES IN MEXICO (2007) Pierre Moïse and Elizabeth Docteur

No. 24 PHARMACEUTICAL PRICING AND REIMBURSEMENT POLICIES IN CANADA (2006) Valérie Paris and Elizabeth Docteur

No. 23 HEALTH CARE QUALITY INDICATORS PROJECT, CONCEPTUAL FRAMEWORK PAPER (2006) Edward Kelley and Jeremy Hurst 
No. 22 HEALTH CARE QUALITY INDICATORS PROJECT, INITIAL INDICATORS REPORT (2006) Soeren Mattke, Edward Kelley, Peter Scherer, Jeremy Hurst, Maria Luisa Gil Lapetra and the HCQI Expert Group Members

No. 21 THE SUPPLY OF PHYSICIAN SERVICES IN OECD COUNTRIES (2006) Steven Simeons and Jeremy Hurst

No. 20 CONSUMER DIRECTION AND CHOICE IN LONG-TERM CARE FOR OLDER PERSONS, INCLUDING PAYMENTS FOR INFORMAL CARE: HOW CAN IT HELP IMPROVE CARE OUTCOMES, EMPLOYMENT AND FISCAL SUSTAINABILITY? (2005) Jens Lundsgaard

No. 19 TACKLING NURSE SHORTAGES IN OECD COUNTRIES (2004) Steven Simoens, Mike Villeneuve and Jeremy Hurst

No. 18 PRIVATE HEALTH INSURANCE IN THE NETHERLANDS. A CASE STUDY (2004) Nicole Tapay and Francesca Colombo

No. 17 SKILL-MIX AND POLICY CHANGE IN THE HEALTH WORKFORCE: NURSES IN ADVANCED ROLES (2004) James Buchan and Lynn Calman

No. 16 SHA-BASED NATIONAL HEALTH ACCOUNTS IN THIRTEEN OECD COUNTRIES: A COMPARATIVE ANALYSIS (2004) Eva Orosz and David Morgan

No. 15 PRIVATE HEALTH INSURANCE IN OECD COUNTRIES: THE BENEFITS AND COSTS FOR INDIVIDUALS AND HEALTH SYSTEMS (2004) Francesca Colombo and Nicole Tapay

No. 14 INCOME-RELATED INEQUALITY IN THE USE OF MEDICAL CARE IN 21 OECD COUNTRIES (2004) Eddy van Doorslaer, Cristina Masseria and the OECD Health Equity Research Group

No. 13 DEMENTIA CARE IN 9 OECD COUNTRIES: A COMPARATIVE ANALYSIS (2004) Pierre Moise, Michael Schwarzinger, Myung-Yong Um and the Dementia Experts' Group

No. 12 PRIVATE HEALTH INSURANCE IN FRANCE (2004) Thomas C. Buchmueller and Agnes Couffinhal

No. 11 THE SLOVAK HEALTH INSURANCE SYSTEM AND THE POTENTIAL ROLE FOR PRIVATE HEALTH INSURANCE: POLICY CHALLENGES (2004) Francesca Colombo and Nicole Tapay

No. 10 PRIVATE HEALTH INSURANCE IN IRELAND. A CASE STUDY (2004) Francesca Colombo and Nicole Tapay

No. 9 HEALTH CARE SYSTEMS: LESSONS FROM THE REFORM EXPERIENCE (2003) Elizabeth Docteur and Howard Oxley

No. 8 PRIVATE HEALTH INSURANCE IN AUSTRALIA. A CASE STUDY (2003) Francesca Colombo and Nicole Tapay 


\section{RECENT RELATED OECD PUBLICATIONS}

HEALTH AT A GLANCE 2009: OECD INDICATORS (2009).

See http://www.oecd.org/health/healthataglance for more information

ACHIEVING BETTER VALUE FOR MONEY IN HEALTH CARE (2009), OECD HEALTH POLICY STUDIES

OECD HEALTH DATA 2009 (2009), available on CD-ROM (in single-user or network installations). The database can be queried in English, French, German, Spanish and Italian. Japanese and Russian are also available but exclusively in the online version. www.oecd.org/health/healthdata

OECD REVIEWS OF HEALTH SYSTEMS - TURKEY (2009)

THE LOOMING CRISIS IN THE HEALTH WORKFORCE: CAN OECD COUNTRIES RESPOND? (2008) PHARMACEUTICAL PRICING POLICIES IN A GLOBAL MARKET(2008)

OECD REVIEWS OF HEALTH SYSTEMS - SWITZERLAND (2006)

LONG-TERM CARE FOR OLDER PEOPLE (2005), OECD HEALTH PROJECT SERIES

HEALTH TECHNOLOGIES AND DECISION MAKING (2005), OECD HEALTH PROJECT SERIES

OECD REVIEWS OF HEALTH CARE SYSTEMS - FINLAND (2005)

OECD REVIEWS OF HEALTH CARE SYSTEMS - MEXICO (2005)

PRIVATE HEALTH INSURANCE IN OECD COUNTRIES (2004), OECD HEALTH PROJECT SERIES

TOWARDS HIGH-PERFORMING HEALTH SYSTEMS - POLICY STUDIES (2004), OECD HEALTH PROJECT SERIES

TOWARDS HIGH-PERFORMING HEALTH SYSTEMS (2004), OECD HEALTH PROJECT SERIES OECD REVIEWS OF HEALTH CARE SYSTEMS - KOREA (2003)

A DISEASE-BASED COMPARISON OF HEALTH SYSTEMS: WHAT IS BEST AND AT WHAT COST? (2003)

MEASURING UP: IMPROVING HEALTH SYSTEMS PERFORMANCE IN OECD COUNTRIES (2002)

For a full list, consult the OECD On-Line Bookstore at www.oecd.org, or write for a free written catalogue to the following address:

OECD Publications Service

2, rue André-Pascal, 75775 PARIS CEDEX 16

or to the OECD Distributor in your country 